\title{
Are stem nectaries common in Gentianaceae Juss.?
}

\author{
Valdnéa Casagrande Dalvi ${ }^{\star *}$, Renata Maria Strozi Alves Meira² and Aristéa Alves Azevedo²
}

Received: November 17, 2016

Accepted: January 31, 2017

\begin{abstract}
Extrafloral nectaries (EFNs) are specialized structures that produce and release nectar and are located on leaves, cotyledons and, more seldomly, stems. Peculiar leaf nectaries have been described for thirty-three Neotropical species of Gentianaceae, while stem nectaries have been reported for only nine. The aim of this study was to verify the occurrence of stem EFNs within Gentianaceae and investigate the existence of a correlation between their occurrence and the geographical distribution of species. Samples of internodal regions from field and herbarium specimens were submitted to standard light microscopy techniques. Data regarding the geographical distribution of species were acquired from herbarium specimens and the literature. A total of 37 species were investigated, representing 25 genera distributed among five tribes. Nectaries, composed of modified epidermal cells, were observed in 16 species restricted to the Neotropical tribes Helieae, Saccifolieae, Potalieae and Coutoubeinae; exceptions were Cicendia quadrangularis and Zygostigma australe, which both occur in the Neotropics but do not possess EFNs. These results demonstrate that stem EFNs are common among Neotropical taxa of Gentianaceae, and are typically absent from taxa in temperate regions.
\end{abstract}

Keywords: Coutoubeinae, Helieae, Potalieae, Saccifolieae, secretory structures

\section{Introduction}

Nectaries are structures that release nectar, a solution composed mainly of mono- and disaccharides, amino acids, proteins and trace amounts of other compounds (Elias 1983; Nicolson \& Thornburg 2007). Extrafloral nectaries (EFNs) play an important ecological role in plant protection, since nectar acts as a carbohydrate-rich liquid reward for ants in exchange for protection against herbivores (Heil 2015; Del-Claro et al. 2016).

EFNs occur in 110 families of vascular tracheophytes, but are unknown in gymnosperms, early angiosperms and magnoliids (Weber \& Keeler 2013; Weber et al. 2015). Although EFNs occur in monocots, the bulk of their occurrence is widespread among eudicots, especially in the rosids clade (Weber \& Keeler 2013). Evidence suggests that EFNs originated a remarkable number of times in the evolution of tracheophytes (Weber \& Keeler 2013) and played a key evolutionary role in the diversification of certain plant clades (Marazzi \& Sanderson 2010; Nogueira et al. 2012).

Although EFNs have been reported to be absent in Gentianaceae Juss. (Elias 1983) peculiar nectaries composed of only modified epidermal cells were described for 33 species of Gentianaceae, including 13 Neotropical genera (Delgado et al. 2011a; b; Dalvi et al. 2013; 2014; Guimarães et al. 2013). Such nectaries are microscopic structures and occur along the leaf blade in single units or aggregates (Dalvi et al. 2013). Anatomically similar nectaries were also observed on the stem of seven species of Curtia, in Hockinia

\footnotetext{
${ }^{1}$ Instituto Federal de Educação, Ciência e Tecnologia Goiano, Rodovia Sul Goiana, Km 01, Zona Rural, 75901-970, Rio Verde, GO, Brazil ${ }^{2}$ Programa de Pós-Graduação em Botânica, Departamento de Biologia Vegetal, Universidade Federal de Viçosa, Av. P.H. Rolfs, s/n, Campus Universitário, 36570-000, Viçosa, MG, Brazil
} 
montana (Dalvi et al. 2014), and in Schultesia pachyphylla (Guimarães et al. 2013). However, a profuse secretion and the presence of ants were observed only in the aggregated leaf nectaries of Calolisianthus speciosus (Delgado et al. 2011a) and Chelonanthus viridiflorus (Dalvi et al. 2013). In both species the nectaries occur at the base of the leaf blade are recognized as yellow areas. As usually described, the nectar of Calolisianthus speciosus is composed of glucose, fructose, and sucrose (Delgado et al. 2011a).

Gentianaceae is comprised of 1700 species and 91 genera organized in seven tribes, Chironieae, Exaceae, Gentianeae, Helieae, Potalieae, Saccifolieae and Voyrieae (Struwe et al. 2002; Merckx et al. 2013; Gentian Research Network 2016). Although this family is cosmopolitan, most of the species occur in temperate regions (Sousa \& Lorenzi 2008), while the greatest diversity of genera lies on South and Central America (Albert \& Struwe 2002).

EFNs have been considered more abundant in species from tropical communities than in those from temperate regions (Oliveira \& Freitas 2004; Rico-Gray \& Oliveira 2007). However, information about the possible influences of geographic regions over the occurrence of EFNs is still scarce (Pemberton 1998). In addition, data about stem EFNs are limited to just a few families, and detailed structural descriptions are lacking (Machado et al. 2008; Weber \& Keeler 2013).

Considering the widespread distribution of Gentianaceae and the usual occurrence of leaf nectaries in Neotropical species, the aim of this study was to investigate how common is the occurrence of stem nectaries in Neotropical and temperate species of Gentianaceae.

\section{Materials and methods}

Samples from the third to fifth internodes were obtained from exsiccates of national and international herbaria (Tab. 1). The material was rehydrated by microwaving in distilled water for $5 \mathrm{~min}$ and left to rest overnight. Rehydrated samples were then treated with $2 \%$ potassium hydroxide for 1-2 h, dehydrated in an ethanol series and stored in $70 \%$ ethanol (Smith \& Smith 1942). According to the occurrence of species, different locations in the states of Minas Gerais and Bahia (Brazil) were selected for field expeditions. In the same way, samples from the third to fifth internodes of field-collected material were fixed in FAA (formalin, acetic acid, $50 \%$ ethanol, 1:1:18 by volume) and stored in $70 \%$ ethanol (Johansen 1940). Voucher materials were deposited in the VIC Herbarium of Universidade Federal de Viçosa (UFV), Minas Gerais, Brazil. Fragments of young branches were sampled only from Potalia resinifera Mart., the unique tree species analyzed here.

For the anatomical studies, samples stored in $70 \%$ ethanol were submitted to an ethanol dehydration series and subsequently embedded in methacrylate (Historesin, Leica Microsystems Nussloch GmbH, Heidelberg, Germany).

Table 1. Sampled Gentianaceae species, organized by tribes, with their collectors (herbaria), collection sites and geographical distribution of tribes, subtribes and species.

\begin{tabular}{|c|c|c|c|}
\hline Tribe/subtribe/species & Collector and herbarium & Local collection & Distribution - Tribe and species \\
\hline CHIRONIEAE - Subtribe Canscorinae & & & $\begin{array}{l}\text { PALEOTROPICAL } \\
\text { (Struwe et al. 2002) }\end{array}$ \\
\hline \multirow{3}{*}{$\begin{array}{l}1 \text { - Canscora diffusa (Vahl) R. Br. ex Roem. } \\
\text { \& Schult. }\end{array}$} & D.A.Nangoma and K.Kaunda 201 (NY) & Malawi, Africa & \multirow{3}{*}{$\begin{array}{l}\text { Asia, India, Africa, Madagascar } \\
\text { and Australia (Thiv \& Kadeiret } \\
\text { 2002) }\end{array}$} \\
\hline & NR (NY) & Cameroon, Africa & \\
\hline & Koyama et al. s.n. (NY) & Doi Inthanon, Thailand & \\
\hline CHIRONIEAE - Subtribe Chironiinae & & & $\begin{array}{l}\text { PANTROPICAL TO TEMPERATE } \\
\text { (Struwe et al. 2002) }\end{array}$ \\
\hline $\begin{array}{l}2 \text { - Blackstonia perfoliata (L.) Huds. subsp } \\
\text { grandiflora }\end{array}$ & J.Lewalle 8763 (NY) & Tétouan, Maroc & $\begin{array}{l}\text { Mediterranean (Mansion \& } \\
\text { Struwe 2004) }\end{array}$ \\
\hline \multirow{3}{*}{3 - Centaurium erythraea Rafn } & I.Cordeiro et al. 2993 (SP) & Rio de Janeiro, Brazil & \multirow{3}{*}{$\begin{array}{l}\text { Mediterranean (Mansion \& } \\
\text { Struwe 2004) }\end{array}$} \\
\hline & H.Luedrewaldt 51 (SP) & Rio de Janeiro, Brazil & \\
\hline & R.Kral 75992 (SP) & São Paulo, Brazil & \\
\hline 4 - Centaurium maritimum (L.) Fritsch & Pajarón 53 (NY) & Los Barrios, Spain & $\begin{array}{l}\text { Mediterranean (Mansion \& } \\
\text { Struwe 2004) }\end{array}$ \\
\hline \multirow{3}{*}{5 - Centauriumpulchellum (Sw.) Druce } & A.W.Cusick 1133 (NY) & Ohio, USA & \multirow{3}{*}{$\begin{array}{l}\text { Mediterranean (Mansion \& } \\
\text { Struwe 2004) }\end{array}$} \\
\hline & A.W.Cusick 34481 (NY) & Ohio, USA & \\
\hline & W.D.Longbotton 13784 (NY) & Maryland, USA & \\
\hline \multirow{3}{*}{6 - Chironia baccifera L. } & H.J.T.Venter 10676 (NY) & South Africa, Africa & \multirow{3}{*}{$\begin{array}{l}\text { Southern Africa (Mansion } \\
\text { \& Struwe 2004); Africa and } \\
\text { Madagascar (Gentian Research } \\
\text { Network 2016) }\end{array}$} \\
\hline & R.Brand et al. 175 (NY) & South Africa, Africa & \\
\hline & NR (NY) & South Africa, Africa & \\
\hline \multirow{3}{*}{7 - Cicendia filiformis Delarbre } & J.Stefani s.n. (US) & NR & \multirow{3}{*}{$\begin{array}{l}\text { Mediterranean and Western } \\
\text { Europe (Struwe et al. 2002) }\end{array}$} \\
\hline & P.Aellen s.n. (US) & Solenzara, France & \\
\hline & J.Stefani s.n. (SP) & NR & \\
\hline
\end{tabular}


Table 1. Cont.

\begin{tabular}{|c|c|c|c|}
\hline Tribe/subtribe/species & Collector and herbarium & Local collection & Distribution - Tribe and species \\
\hline \multirow{3}{*}{8 - Cicendia quadrangularis (Lam.) Griseb. } & H.W.Camp 3516 (NY) & Chimborazo, Ecuador & \multirow{3}{*}{$\begin{array}{l}\text { Mediterranean (Mansion } \\
\& \text { Struwe 2004); disjunct } \\
\text { distribution in Southern and } \\
\text { Western North America; and } \\
\text { South America, from Ecuador to } \\
\text { Argentina (Struwe et al. 2002) }\end{array}$} \\
\hline & B.Ertter et al. s.n. (NY) & California, USA & \\
\hline & NR (NY) & California, USA & \\
\hline \multirow{2}{*}{$\begin{array}{l}9 \text { - Gyrandra tenuiflora (Martens \& } \\
\text { Galeotti) Mansion }\end{array}$} & A.Neil and B.R.Harriman s.n. (NY) & Ozaukee, USA & \multirow{2}{*}{$\begin{array}{l}\text { Mountains of Western Mexico } \\
\text { (Mansion 2004) }\end{array}$} \\
\hline & T.Gviniashvili et al. 464 (NY) & Georgia, USA & \\
\hline \multirow{3}{*}{10 - Sabatia angularis (L.) Pursh } & J.B.Nelson and A.Aurich 16714 (NY) & South Carolina, USA & \multirow{3}{*}{$\begin{array}{l}\text { USA (Gentian Research Network } \\
\text { 2016) }\end{array}$} \\
\hline & F.W.H. $10462(\mathrm{NY})$ & North Carolina, USA & \\
\hline & R.Dale Thomas 124348 (NY) & Louisiana, USA & \\
\hline \multirow[t]{2}{*}{11 - Sabatia campestris Nutt. } & $\begin{array}{l}\text { G.L.Webster and R.L.Wilbur } 3261 \\
\text { (NY) } \\
\text { R.Dale Thomas } 100115 \text { (NY) }\end{array}$ & $\begin{array}{l}\text { Louisiana, USA } \\
\text { Louisiana, USA }\end{array}$ & \multirow[t]{2}{*}{$\begin{array}{l}\text { USA (Gentian Research Network } \\
\text { 2016) }\end{array}$} \\
\hline & R.Dale Thomas and C. Amazon (NY) & Louisiana, USA & \\
\hline \multirow{3}{*}{12 - Schenkia spicata (L.) Mansion } & J.Risler and R.A.Kerrigan 403 (NY) & Alroy Downs, Australia & \multirow{3}{*}{$\begin{array}{l}\text { Mediterranean (Mansion \& } \\
\text { Struwe 2004); Western Europe } \\
\text { to Eastern Asia and North Africa; } \\
\text { introduced in North America } \\
\text { (Mansion 2004) }\end{array}$} \\
\hline & D.E.Symon 15270 (NY) & South Australia, Australia & \\
\hline & H.P. Vonow 911 (NY) & South Australia, Australia & \\
\hline \multirow{3}{*}{13 - Zeltnera stricta (Schiede) Mansion } & C.R.Broome and R.M. Lloyd 634 (NY) & Mexico & \multirow{3}{*}{$\begin{array}{l}\text { Endemic to South and Central } \\
\text { Mexico (Mansion 2004) }\end{array}$} \\
\hline & C.R.Broome $746(\mathrm{NY})$ & Mexico & \\
\hline & C.R.Broome and R.M. Lloyd 620 (NY) & Mexico & \\
\hline \multirow{3}{*}{$\begin{array}{l}14 \text { - Zygostigma australe (Cham. \& } \\
\text { Schltdl.) Griseb. }\end{array}$} & G.Hatschbach et al. 71812 (MBM) & Paraná, Brazil & \multirow{3}{*}{$\begin{array}{l}\text { Brazil, Argentina and Uruguay } \\
\text { (Struwe et al. 2002) }\end{array}$} \\
\hline & A.Usteri s.n. (SP) & São Paulo, Brazil & \\
\hline & F.C.Hoehne s.n. (SP) & São Paulo, Brazil & \\
\hline CHIRONIEAE - Subtribe Coutoubeinae & & & $\begin{array}{l}\text { NEOTROPICAL (Struwe et al. } \\
\text { 2002) }\end{array}$ \\
\hline \multirow{3}{*}{15 - Symphyllophyton caprifolioides Gilg } & J.A.Ratter et al. 6742 (INPA) & Maranhão, Brazil & \multirow{3}{*}{$\begin{array}{l}\text { South America (Mansion } \\
\text { \& Struwe 2004); and Brazil } \\
\text { (Guimarães \& Saavedra 2013) }\end{array}$} \\
\hline & $\begin{array}{l}\text { I.Gottesberg and G.Gottesberg s.n. } \\
\text { (SP) }\end{array}$ & Goiás, Brazil & \\
\hline & J.A.Ratter et al. s.n. (MBM) & Maranhão, Brazil & \\
\hline \multirow{3}{*}{16 - Xestaea lisianthoides Griseb. } & P.H.Gentle 9052 (US) & Cayo, Honduras & \multirow{3}{*}{$\begin{array}{l}\text { Central and South America } \\
\text { (Struwe et al. 2002) }\end{array}$} \\
\hline & P.C.Standley 30379 (US) & France Field, Panama & \\
\hline & E.P.Killip 3362 (US) & Panama & \\
\hline GENTIANEAE - Subtribe Gentianinae & & & $\begin{array}{l}\text { TEMPERATE-ALPINE (Struwe et } \\
\text { al. 2002) }\end{array}$ \\
\hline \multirow{3}{*}{17 - Gentiana sedifolia H. B. K. } & $\begin{array}{l}\text { L.B.Holm-Nielsen and J. Jamarilho } \\
\text { s.n. (US) }\end{array}$ & Tungurahua, Ecuador & \multirow{3}{*}{$\begin{array}{l}{ }^{*} \text { Asia, Europe, North and South } \\
\text { America, Northwest Africa, and } \\
\text { East Australia (Struwe et al. 2002) }\end{array}$} \\
\hline & P. Acevedo-Rodzg s.n. (US) & Cochabamba, Bolivia & \\
\hline & John L. Clark 719 (US) & Tungurahua, Ecuador & \\
\hline GENTIANEAE - Subtribe Swertiinae & & & $\begin{array}{l}\text { TEMPERATE-ALPINE (Struwe et } \\
\text { al. 2002) }\end{array}$ \\
\hline \multirow{2}{*}{18 - Bartoniapaniculata (Michx.) Muhl. } & L.K. Magrath 17310 (NY) & Oklahoma, USA & \multirow{2}{*}{$\begin{array}{l}{ }^{*} \text { North America, from Texas and } \\
\text { Florida to Newfoundland (Struwe } \\
\text { et al. 2002) }\end{array}$} \\
\hline & H.E. Ahles 36920 (NY) & North Carolina, USA & \\
\hline \multirow{3}{*}{$\begin{array}{l}19 \text { - Bartonia virginica (L.) Britton, Sterns } \\
\& \text { Poggenb }\end{array}$} & M.L. Fernald s.n. (NY) & Nova Scotia, Canada & \multirow{3}{*}{$\begin{array}{l}{ }^{*} \text { North America, from Texas and } \\
\text { Florida to Newfoundland (Struwe } \\
\text { et al. 2002) }\end{array}$} \\
\hline & R.C.Bean and D. White s.n. (NY) & Nova Scotia, Canada & \\
\hline & M.L. Fernald and B. Long s.n. (NY) & Nova Scotia, Canada & \\
\hline \multirow{3}{*}{20 - Gentianella amarella (L.) Börner } & C.G. Alm s.n. (NYBG) & Torneträsk, Sweden & \multirow{3}{*}{$\begin{array}{l}\text { Europe and North America } \\
\text { (Gentian Research Network } \\
\text { 2016) }\end{array}$} \\
\hline & N.Jacobsen and J. Suedsen s.n. (NY) & NR & \\
\hline & Harry Smith s.n. (NY) & Sweden & \\
\hline & H.H.Iltis et al. 636 (NY) & Siberia & Asia (Hagen 2003) \\
\hline 21 - Halenia corniculata (L.) Cornaz & N.Naruhashi s.n. (NY) & Hokkaido, Japan & \\
\hline & H.H.Iltis et al. 873 (NY) & Lake Baikal, Siberia & \\
\hline
\end{tabular}


Table 1. Cont.

\begin{tabular}{|c|c|c|c|}
\hline Tribe/subtribe/species & Collector and herbarium & Local collection & Distribution - Tribe and species \\
\hline \multirow{3}{*}{22 - Halenia palmeri A. Gray } & Rogers McVaugh 21741 (NY) & Durango, Mexico & \multirow{3}{*}{ Mexico (Hagen 2003)) } \\
\hline & $\begin{array}{l}\text { N/H. Holmgren and T. K. Lowrey } \\
8073 \text { (NY) }\end{array}$ & Durango, Mexico & \\
\hline & F.W.Pennell s.n. (NY) & Durango, Mexico & \\
\hline \multirow{3}{*}{$\begin{array}{l}23 \text { - Lomatogonium carinthiacum (Wulf.) } \\
\text { Rchb. }\end{array}$} & V.Zuer (NY) & Altai, Russia & \multirow{3}{*}{$\begin{array}{l}\text { *North America, temperate Asia, } \\
\text { and Europe (Struwe et al. 2002) }\end{array}$} \\
\hline & Otar Abdalazed et al. 686 (NY) & Kazbegi, Georgia & \\
\hline & $\begin{array}{l}\text { G.Nakahutsrishvili and O.Abdalazed } \\
160 \text { (NY) }\end{array}$ & Kazbegi, Georgia & \\
\hline HELIEAE & & & $\begin{array}{l}\text { NEOTROPICAL (Struwe et al. } \\
\text { 2002) }\end{array}$ \\
\hline \multirow{2}{*}{24 - Adenolisianthus arboreus Gilg } & $\begin{array}{l}\text { J.J.Wurdack and L.S.Adderley s.n. } \\
\text { (NY) }\end{array}$ & Amazonas, Brazil & \multirow{2}{*}{ South America (Lepis 2009) } \\
\hline & B.G.S.Ribeiro 1060 (RB) & Amazonas, Brazil & \\
\hline \multirow{3}{*}{$\begin{array}{l}25 \text { - Calolisianthuspedunculatus (Cham. \& } \\
\text { Schltdl.) Gilg }\end{array}$} & V.C.Dalvi et al. 98 (VIC) & Minas Gerais, Brazil & \multirow{3}{*}{ Brazil (Calió 2009) } \\
\hline & V.C.Dalvi et al. 102 (VIC) & Minas Gerais, Brazil & \\
\hline & V.C.Dalvi et al. 109 (VIC) & Minas Gerais, Brazil & \\
\hline \multirow{3}{*}{26 - Calolisianthus speciosus Gilg } & G.Valente et al. 1969(VIC) & Minas Gerais, Brazil & \multirow{3}{*}{ Brazil (Calió 2009) } \\
\hline & G.Valente et al. 1941 (VIC) & Minas Gerais, Brazil & \\
\hline & G.Valente et al. 2237 (VIC) & Minas Gerais, Brazil & \\
\hline \multirow{3}{*}{27 - Chelonanthus alatus (Aubl.) Pulle } & C.Todzia et al. 2213(INPA) & Amazonas, Brazil & \multirow{3}{*}{$\begin{array}{l}\text { Central and South America (Lepis } \\
\text { 2009) }\end{array}$} \\
\hline & E.Brocki 14 (INPA) & Amazonas, Brazil & \\
\hline & M.Groppo Jr. et al. 956 (INPA) & Amazonas, Brazil & \\
\hline \multirow{4}{*}{$\begin{array}{l}28 \text { - Chelonanthus albus (Spruce ex Progel) } \\
\text { Badillo }\end{array}$} & $\begin{array}{l}\text { F.E.Miranda and M.C.C. Miranda } 829 \\
\text { (INPA) }\end{array}$ & Amazonas, Brazil & \multirow{4}{*}{$\begin{array}{l}\text { Central and South America (Lepis } \\
\text { 2009) }\end{array}$} \\
\hline & J.Chagas s.n. (INPA) & Amazonas, Brazil & \\
\hline & $\begin{array}{l}\text { W.Rodrigues and J. Chagas } 4503 \\
\text { (INPA) }\end{array}$ & Amazonas, Brazil & \\
\hline & P.J.Maas et al s.n. (NY) & Amazonas, Brazil & \\
\hline \multirow{3}{*}{$\begin{array}{l}29 \text { - Chelonanthus grandiflorus (Aubl.) } \\
\text { Chodat \& E. Hassl. }\end{array}$} & M.F.Silva et al. 618 (INPA) & Amazonas, Brazil & \multirow{3}{*}{$\begin{array}{l}\text { Central and South America (Lepis } \\
\text { 2009) }\end{array}$} \\
\hline & L.A.Maia et al 403 (INPA) & Amazonas, Brazil & \\
\hline & D.W.Stevenson et al. s./n. (INPA) & Amazonas, Brazil & \\
\hline \multirow{3}{*}{$\begin{array}{l}30 \text { - Chelonanthus purpurascens (Aubl.) } \\
\text { Struwe, S. Nilsson \& V.A. Albert }\end{array}$} & V.C.Dalvi et al. 34 (VIC) & Bahia, Brazil & \multirow{3}{*}{ South America (Lepis 2009) } \\
\hline & V.C.Dalvi et al. 52 (VIC) & Bahia, Brazil & \\
\hline & V.C.Dalvi et al. 61 (VIC) & Bahia, Brazil & \\
\hline \multirow{3}{*}{31 - Chelonanthus viridiflorus (Mart.) Gilg } & J. A. Ratter et al. s.n. (INPA) & Roraima, Brazil & \multirow{3}{*}{ South America (Lepis 2009) } \\
\hline & $\begin{array}{l}\text { V.CDalvi and D,M,T,F.Francino } 03 \\
\text { (VIC) }\end{array}$ & Minas Gerais, Brazil & \\
\hline & $\begin{array}{l}\text { V.C.Dalvi and D.M.T.F.Francino } 12 \\
\text { (VIC) }\end{array}$ & Minas Gerais, Brazil & \\
\hline \multirow{3}{*}{ 32- Helia oblongifolia Mart. } & M.M.K. Carra and P. J .M. Maas (SP) & NR & \multirow{3}{*}{ Brazil and Paraguay (Calió 2009) } \\
\hline & M.F. Calió 205 et al. (SPF) & Minas Gerais, Brazil & \\
\hline & A.C.Brade s.n. (SP) & São Paulo, Brazil & \\
\hline \multirow{2}{*}{$\begin{array}{l}33 \text { - Irlbachia nemorosa (Willd. ex Roem. \& } \\
\text { Schult.) Merr. }\end{array}$} & $\begin{array}{l}\text { W.Montovani and D.M.S.Rocha s.n. } \\
\text { (SPF) }\end{array}$ & Amazonas, Brazil & \multirow{2}{*}{$\begin{array}{l}\text { Brazil (Guimarães \& Saavedra } \\
\text { 2013) }\end{array}$} \\
\hline & Fábio de Barros 947 (SP) & Amazonas, Brazil & \\
\hline \multirow{3}{*}{$\begin{array}{l}34 \text { - Tetrapollinia caerulescens (Aubl.) } \\
\text { Maguire \& B.M. Boom }\end{array}$} & R.M.Harley et al 25990 (SP) & Bahia, Brazil & \multirow{3}{*}{$\begin{array}{l}\text { Central and South America } \\
\text { (Gentian Research Network } \\
\text { 2016) }\end{array}$} \\
\hline & M.F.Calió et al 154 (SPF) & Minas Gerais, Brazil & \\
\hline & Fábio de Barros 862 (SP) & $\begin{array}{l}\text { Mato Grosso do Sul, } \\
\text { Brazil }\end{array}$ & \\
\hline POTALIEAE - Subtribe Faroinae & & & $\begin{array}{l}\text { PANTROPICAL (Struwe et al. } \\
\text { 2002) }\end{array}$ \\
\hline
\end{tabular}


Table 1. Cont.

\begin{tabular}{|c|c|c|c|}
\hline Tribe/subtribe/species & Collector and herbarium & Local collection & Distribution - Tribe and species \\
\hline \multirow{4}{*}{$\begin{array}{l}35 \text { - Neurotheca loeselioides (Spruce ex } \\
\text { Progel) Baill. }\end{array}$} & M.N.Silva et al. 182 (INPA) & Pará, Brazil & \multirow{4}{*}{$\begin{array}{l}\text { Northern South America, tropica } \\
\text { Africa, and Western Madagascar } \\
\text { (Struwe et al. 2002) }\end{array}$} \\
\hline & B.W.Nelson et al. 1483 (INPA) & Amazonas, Brazil & \\
\hline & $\begin{array}{l}\text { O.P.Monteiro and J.F.Ramos } 832 \\
\text { (INPA) }\end{array}$ & Amazonas, Brazil & \\
\hline & A.Janssen 131 (RB) & Amazonas, Brazil & \\
\hline POTALIEAE - Subtribe Potaliinae & & & $\begin{array}{l}\text { PANTROPICAL (Struwe et al. } \\
\text { 2002) }\end{array}$ \\
\hline \multirow{3}{*}{36 - Potalia resinifera Mart. } & N.A.Rosa et al. 5487 (SPF) & Amazonas, Brazil & \multirow{3}{*}{$\begin{array}{l}\text { Brazil (Amazonas) and Andes } \\
\text { (Struwe \& Albert 2004) }\end{array}$} \\
\hline & M.Goppo et al. 882 (SPF) & Amazonas, Brazil & \\
\hline & $\begin{array}{l}\text { A.Henderson and F.G.Padilha } 2034 \\
\text { (NY) }\end{array}$ & Loreto, Peru & \\
\hline SACCIFOLIEAE & & & $\begin{array}{l}\text { NEOTROPICAL (Struwe et al. } \\
\text { 2002) }\end{array}$ \\
\hline \multirow{3}{*}{37 - Voyriella parviflora Miq. } & M.J.Pires and N.T.Silva 1641 (NY) & Pará, Brazil & \multirow{3}{*}{$\begin{array}{l}\text { South America and Panama } \\
\text { (Struwe et al. 2002) }\end{array}$} \\
\hline & $\begin{array}{l}\text { E.A.Chritenson and S.R.George } 1796 \\
\text { (NY) }\end{array}$ & French Guiana & \\
\hline & Bassett Maguire et al. s.n. (NY) & Suriname & \\
\hline
\end{tabular}

$\left(^{*}\right)$ Distribution pattern of the genus. NR= Not reported. Acronyms of herbaria according to Index Herbariorum.

The material was sectioned using a rotary microtome (model RM2155, Leica Microsystems Inc., Deerfield, USA). Cross and paradermal sections ( $7 \mu \mathrm{m}$ thick) were stained with toluidine blue, pH 4.7 (O' Brien et al. 1964), and permanent slides were mounted with synthetic resin (Permount, Fisher Scientific, New Jersey, USA). To observe epidermal cells from frontal view, paradermal hand-sections were obtained, clarified in sodium hypochlorite (20\%), stained with 0.001 $\%$ basic alcoholic fuchsin and mounted in gelatin (Johansen 1940).

Analyses and image captures were conducted using an Olympus Optical AX70TRF (Tokyo, Japan) with a U-Photo system and coupled digital camera (AxioCam HRc; Zeiss, Göttingen, Germany) in the Laboratory of Plant Anatomy of UFV.

The data for the geographical distribution of species and tribes/subtribes/genera/species were obtained from herbarium data and literature (Tab.1).

\section{Results}

We analyzed 37 species (25 genera), comprising representatives of the tribes Chironieae, Gentianeae, Helieae, Potalieae and Saccifolieae (Tab. 1). The stem EFNs were not visible to the naked eye neither in materials collected in the field nor in those from herbaria. Conversely, secretion or other macro-morphological evidence of the presence of these nectaries was not detected as well. However nectaries were observed under light microscopy on internodes of the stems in 16 species of 11 genera comprising almost $50 \%$ of taxa studied (Tab. 1).
The stem nectaries are non-vascularized glands comprised of a single central epidermal cell surrounded by concentrically arranged secretory cells, as shown in Chelonanthus purpurascens (Fig. 1A, B) and Tetrapollinia caerulescens (Fig. 1C, D). The region of contact between secretory cells and the central cell stained intensely with toluidine blue (Fig. 1E, F). Stem nectaries have a scattered distribution and are interspersed among stomata, except in Potalia resinifera, where stomata were not detected.

In the tribe Helieae, stem nectaries were observed in all analyzed species (Tab. 1). Voyriella parviflora was the only species of tribe Saccifolieae analyzed that bore stem nectaries. The presence of stem nectaries was ubiquitous in Potalieae. On the other hand, stem nectaries were absent in seven analyzed taxa of the tribe Gentianeae. In Chironieae, stem nectaries were present in three species from different genera. In Coutoubeinae, Canscorinae and Chironiinae the pattern of presence or absence of stem nectaries remained constant. Two species of Coutoubeinae, Symphyllophytton caprifolioides (Fig. 1E) and Xestaea lisianthoides (Fig. 1F), bore stem nectaries, while they were not detected in Canscorinae (Canscora diffusa) and in Chironiinae (Tab. 1).

Regarding the correlation between presence/absence of stem nectaries and pattern of geographic distribution of species, tribes or subtribes, the presence of these nectaries was constant in species restricted to the Neotropics, including all species of tribes Helieae, Saccifolieae, subtribe Coutoubeinae (Chironieae) and Potalia resinifera (Potalieae - Potaliinae) (Tab. 1). Besides occurring in the Neotropics, Neurotheca loeselioides (Potalieae-Faroinae) is also found in Africa and bears stem nectaries. Exceptions could be seen in Chironieae, in which Cicendia quadrangularis 

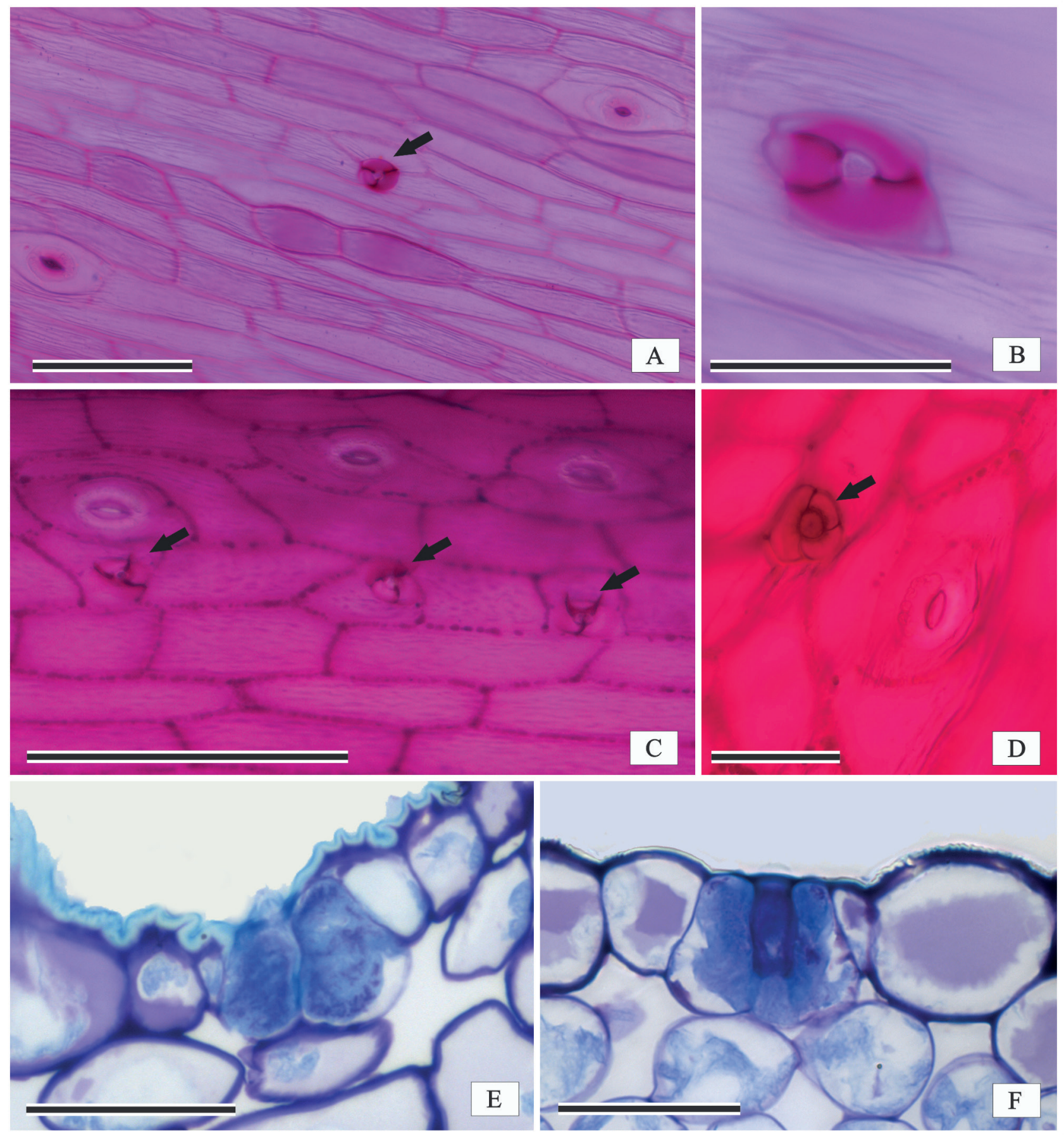

Figure 1. Stem nectaries of species of Gentianaceae in paradermal (A-D) and cross sections (E, F). (A) and (B) Chelonanthus purpurascens. (C) and (D) Tetrapollinia caerulescens. (E) Symphyllophytton caprifolioides. (F) Xestaea lisianthoides. Black arrows indicate EFNs. Bars $=50 \mu$.

and Zygostigma australe (Chironieae - Chironiinae), both occurring in South America, do not possess stem nectaries. In contrast, nectaries are absent in all species restricted to temperate-alpine regions (Gentianinae), as well as in species restricted to the Paleotropics (Chironieae - Canscorinae) and in those distributed in the Pantropics to temperate regions (Chironieae - Chironiinae) (Tab. 1).

\section{Discussion}

The present work demonstrates that in Gentianaceae stem nectaries are common, occurring in $50 \%$ of the studied species, and mainly in Neotropical taxa. These results are interesting since the presence of stem nectaries is considered 
an uncommon character in eudicotyledon families (Elias 1983; Machado et al. 2008). Nectaries of the Gentianaceae were described by Vogel (1998) as unusual nectaries on the sepals of species of Irlbachia and were termed nectarioles by the author. Dalvi et al. (2013) named such structures present on leaves as epidermal nectaries, following the classification proposed by Bernadello (2007).

The lack of evidences regarding the occurrence of stem nectaries in Gentianaceae is due to the absence of microscopic analyses, as also stated by Dalvi et al. (2013) for leaf nectaries. Additionally, anatomical studies of the stem in the species of Gentianaceae are even scarcer than those performed with leaves, and are restricted to a few species of Deianira, Schultesia (Delgado et al. 2009; Guimarães et al. 2013), Curtia and Hockinia (Dalvi et al. 2014). In these genera, stem nectaries were reported for only seven species of Curtia, Hockinia montana and Schultesia pachyphylla. Besides demonstrating that stem nectaries are common in Gentianaceae, the present study highlights the importance of anatomical analysis to confirm the presence of these structures in this family.

Anatomically, the stem nectaries of Gentianaceae are similar to most of the leaf nectaries found in the family (Delgado et al. 2011a; b; Dalvi et al. 2013; 2014; Guimarães et al. 2013), with the exception of those on the leaf base of Calolisianthus speciosus, which are vascularized (Delgado et al. 2011a). Stem nectaries are randomly distributed and do not form aggregates, as observed for leaf nectaries of certain species of Gentianaceae (Dalvi et al. 2013). This pattern of distribution may explain why the exudate is not observed in the field. Abundant nectar was reported only for leaf nectaries of species of Calolisianthus, which occur aggregated at the leaf base (Delgado et al. 2011a). In other species of Gentianaceae, which have isolated nectaries dispersed along the leaf blade, an apparent secretion was also not detected (Delgado et al. 2011a; Dalvi et al. 2013; 2014).

The presence of visible secretion in the field may also be related to the stage of development of the organ, to the season and to the time of day in which the plant was collected. Delgado et al. (2011a) noted that in species of Calolisianthus, it is impossible to collect nectar during the dry season because the secretory cells are not active. Therefore, field studies are necessary to investigate the patterns of nectar secretion related to the environmental factors and to clarify the role played by both leaf and stem nectaries.

In the present study, a correlation between the presence of stem nectaries and geographic distribution of species, subtribes or tribes were indeed observed in Gentianaceae, since among all studied species only those restricted to the Neotropics bore stem nectaries. The Neotropics is a center of diversification of Gentianaceae and comprises the lineages of the most basal nodes of the clade, represented by Saccifolieae (Albert \& Struwe 2002). The presence of units of stem nectaries could represent an ancestral condition in Gentianaceae. On the other hand, the non-occurrence of stem nectaries in the studied species of temperate and paleotropical regions suggests the loss of this structure in the species of these regions. However, futures studies focusing on combinations of morphoanatomical and molecular data are necessary to elucidated how nectaries evolved in Gentianaceae.

Zygostigma australis and Cicendia quadrangularis, both of the subtribe Chironiinae (Chironieae), represent the exceptions to the correlation described above since they occur in Neotropical regions but do not bear stem nectaries. Cicendia quadrangularis is pantropical, while Zygostigma australis is restricted to the South Region of Brazil. This variation represents an interesting model to test the hypothesis proposed by Pemberton (1998) that the incidence of plants bearing EFNs increases along the latitudinal gradient (cold temperate to warm subtropical regions).

The presence of stem nectaries corresponds with the presence of leaf nectaries in Gentianaceae, as reported by Dalvi et al. (2013). The stem nectaries in Gentianaceae are peculiar and originate exclusively by protoderm activity. The underlying premise that the presence of stem nectaries is common in Neotropical, and their absence typical among the temperate, Gentianaceae taxa is confirmed here.

\section{Acknowledgements}

The authors thank FAPEMIG (Research Foundation of the state of Minas Gerais, Brazil) for financial support, CNPq (Conselho Nacional de Desenvolvimento Científico e Tecnológico) for the Research Productivity Scholarships, and CAPES (Coordenação de Aperfeiçoamento de Pessoal de Nivel Superior) for granting a Doctoral Scholarship to V.C. Dalvi. We thank the Instituto Estadual de Florestas de Minas Gerais (IEF-MG) and the Instituto Chico Mendes for providing the licenses to collect samples and the herbarium curators for providing materials for the study.

\section{References}

Albert VA, Struwe L. 2002. Gentianaceae in context. In: Struwe L, Albert VA. (eds.) Gentianaceae: Systematic and Natural History. Cambridge, Cambridge University Press. p. 1-20.

Bernardello G. 2007. A systematic survey of fl oral nectaries. In: Nicolson SW, Nepi M, Pacini E. (eds.) Nectaries and nectar. Dordrecht, Springer. p. 19-128.

Calió MFA. 2009. Sistemática de Helieae Gilg (Gentianaceae). PhD Thesis. Universidade de São Paulo, São Paulo.

Dalvi VC, Meira RMSA, Azevedo AA. 2013. Extrafloral nectaries in neotropical Gentianaceae: occurrence, distribution patterns and anatomical characterization. American Journal of Botany 100: 1-11.

Dalvi VC, Meira RMSA, Francino DMT, Silva LC, Azevedo AA. 2014. Anatomical characteristics as taxonomic tools for the species of Curtia and Hockinia (Saccifolieae-Gentianaceae Juss.). Plant Systematics and Evolution 300: 99-112.

Del-Claro K, Rico-Gray V, Torezan-Silingardi HM, et al. 2016. Loss and gains in ant-plant interactions mediated by extrafloral nectar: fidelity, cheats, and lies. International Journal for the Study of Social Arthropds 63: 207- 221. 
Delgado MN, Azevedo AA, Valente GE, Kasuya MCM. 2009. Morfoanatomia comparada de espécies da subtribo Coutoubeinae (Chironieae-Gentianaceae). Acta Botanica Brasilica 23: 956-967.

Delgado MN, Azevedo AA, Valente GE, Kasuya MCM. 2011b. Comparative anatomy of Calolisianthus species (Gentianaceae-Helieae) from Brazil: taxonomic aspects. Edinburgh Journal of Botany 68: 139-155.

Delgado MN, Silva LC, Báo SN, Morais HC, Azevedo AA. 2011a. Distribution, structural and ecological aspects of the unusual leaf nectaries of Calolisianthus species (Gentianaceae). Flora 206: 676-683.

Elias TS. 1983. Extrafloral nectaries: Their structure and distribution. In: Bentley B, Elias T. (eds.) The Biology of Nectaries. New York, Columbia University Press. p. 174-203.

Gentian Research Network. 2016. Newest Classification of Gentianaceae. http://gentian.rutgers.edu/. 03 Set. 2016.

Guimarães EF, Dalvi VC, Azevedo AA. 2013. Morphoanatomy of Schultesia pachyphylla (Gentianaceae): a discordant pattern in the genus. Botany 91: 830-839.

Guimarães EF, Saavedra MM. 2013. Schultesia. Publishing In: Lista de Espécies da Flora do Brasil. Jardim Botânico do Rio de Janeiro. http:// floradobrasil.jbrj.gov.br/2012/FB000117. 03 Set. 2016.

Hagen KB, Kadereit JW. 2003. The diversification of Halenia (Gentianaceae): Ecological Opportunity Versus Key Innovation. Evolution 57: 25072518.

Heil M. 2015. Extrafloral nectar at the plant-insect interface: a spotlight on chemical ecology, phenotypic plasticity, and food webs. Annual Review of Entomology 60: 213-32.

Johansen DA. 1940. Plant microtechnique. New York, McGraw-Hill Book.

Lepis KB. 2009. Evolution and systematics of Chelonanthus (Gentianaceae). PhD Thesis. The State University of New Jersey, New Brunswick.

Machado SR, Morellato LPC, Sajo MG, Oliveira OS. 2008. Morphological patterns of extrafloral nectaries in woody plant species of the Brazilian cerrado. Plant Biology 10: 660-673.

Mansion G. 2004. A new classification of the polyphyletic genus Centaurium Hill (Chironiinae, Gentianaceae): description of the New World endemic Zeltnera, and reinstatement of Gyrandra Griseb. and Schenkia Griseb. Taxon 53: 719-740.

Mansion G, Struwe L. 2004. Generic delimitation and phylogenetic relationships within the subtribe Chironiinae (Chironieae: Gentianaceae), with special reference to Centaurium: evidence from nrDNA and cpDNA sequences. Molecular Phylogenetics and Evolution 32: 951-977.

Marazzi B, Sanderson MJ. 2010. Large-scale patterns of diversification in the widespread legume genus Senna and the evolutionary role of extrafloral nectaries. Evolution 64: 3570-3592.

Merckx VSFT, Kissling J, Hentrich H, et al. 2013. Phylogenetic relationships of the mycoheterotrophic genus Voyria and the implications for the biogeographic history of Gentianaceae. American Journal of Botany 100: 712-721.

Nicolson SW, Thornburg RW. 2007. Nectar chemistry. In: Nicolson SW, Nepi M, Pacini E. (eds.) Nectaries and Nectar. Dordrecht,Springer. p. 215-264.

Nogueira A, Rey PJ, Lohmann LG. 2012. Evolution of extrafloral nectaries: adaptive process and selective regime changes from forest to savanna. Journal of Evolutionary Biology 25: 2325-2340.

O'Brien TP, Feder N, McCully ME. 1964. Polychromatic staining of plant cell walls by toluidine blue. Protoplasma 59: 368-373.

Oliveira PS, Freitas AVL. 2004. Ant plant herbivore interactions in the neotropical cerrado savanna. Naturwissenschaften 91: 557-570.

Pemberton RW. 1998. The occurrence and abundance of plants with extrafloral nectaries, the basis for antiherbivore defensive mutualisms, along a latitudinal gradient in east Asia. Journal of Biogeography 25: 662-668.

Rico-Gray V, Oliveira PS. 2007. The ecology and evolution of ant-plant interactions. Chicago, The University of Chicago Press.

Smith FH, Smith EC. 1942. Anatomy of the inferior ovary of Darbya. American Journal of Botany 29: 464-471.

Souza VC, Lorenzi H. 2008. Botânica sistemática: guia ilustrado para identificação das famílias de Angiospermas da flora brasileira, baseado em APG II. Nova Odessa, Instituto Plantarum.

Struwe L, Albert VA. 2004. A monograph of Neotropical Potalia Aublet (Gentianaceae: Potalieae). Systematic Botany 29: 670-701.

Struwe L, Kadereit W, Klackenberg J, et al. 2002. Systematics, character evolution, and biogeography of Gentianaceae, including a new tribal and subtribal classification. In: Struwe L, Albert VA. (eds.) Gentianaceae: Systematic and Natural History. Cambridge, Cambridge University Press. p. 21-309.

Thiv M, Kadereit JW. 2002. A morphological cladistic analysis of Gentianaceae-Canscorinae and the evolution of anisomorphic androecia in the sutribe. Systematic Botany 27: 780-788.

Vogel S. 1998. Remarkable nectaries: structure, ecology, organophyletic perspectives. II. Nectarioles. Flora 193: 1-29.

Weber MG, Keeler KH. 2013. The phylogenetic distribution of extrafloral nectaries in plants. Annals of Botany 111: 1251-1261.

Weber MG, Porturas LD, Keeler KH. 2015. World list of plants with extrafloral nectaries. www.extrafloralnectaries.org. 05 Nov. 2016. 